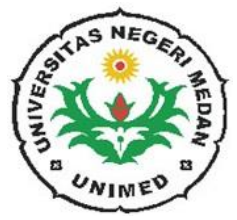

\author{
JBIO: JURNAL BIOSAINS \\ (The Journal of Biosciences) \\ http://jurnal.unimed.ac.id/2012/index.php/biosains \\ email : jbiosains@unimed.ac.id
}

\title{
KAJIAN AWAL KONDISI KESEHATAN HUTAN MANGROVE DI DESA KURAU TIMUR KABUPATEN BANGKA TENGAH PROPINSI KEPULAUAN BANGKA BELITUNG
}

\author{
Arthur Muhammad Farhaby \\ Jurusan Manajemen Sumberdaya Perairan, Universitas Bangka Belitung, Balunijuk \\ Email korespondensi : amfarhaby88@gmail.com
}

Diterima: Juli 2019; Direvisi: September 2019; Disetujui: Oktober 2019

\begin{abstract}
ABSTRAK
Hutan mangrove merupakan salah satu ekosistem yang terdapat di Kurau Timur dengan berbagai dampak positif yang dimilki menjadikan mangrove tersebut salah satu nilai penting bagi masyarakat disana. Ancaman yang terjadi pada kawasan hutan mangrove di kabupaten Bangka Tengah adalah banyaknya dijumpai aktivitas - aktivitas tambang timah inkonvensional yang marak dilakukan oleh masyarakat. Untuk itu diperlukan suatu kajian mengenai kondisi kesehatan hutan mangrove di kawasan tersebut, guna mengetahui bagaimana pengaruh dari aktifitas kegiatan manusia terhadap kondisi kesehatan mangrove di Kurau Timur. Penelitian dilakukan pada bulan Februari sampai Mei 2019 di Desa Kurau Timur. Data penelitian meliputi kerapatan dan indeks nilai penting dan fotografi hemisfer yang telah disepakati untuk pelaksanaan monitoring mangrove kawasan COREMAP-CTI.Berdasarkan hasil pengamatan Desa Kurau timur memiliki tutupan mangrove antara $77.22 \pm 2.64 \%$ sampai $88.89 \pm 1.71 \%$. Nilai tersebut termasuk kedalam kategori baik apabila mengacu pada Keputusan Menteri Lingkungan Hidup No. 201 tahun 2004. Jenis yang mendominasi pada stasiun ini adalah Rhizophora apiculata dengan nilai indeks nilai penting sebesar 148, 13\% hingga 191.02\%. Mayoritas substrat pada lokasi penelitian adalah lumpur berpasir sehingga menjadi habitat yang baik bagi tanaman mangrove terutama jenis Kelompok Rhizophora apiculata yang mendominasi hampir disemua lokasi penelitian
\end{abstract}

\section{Kata Kunci : Desa Kurau Timur, Kerapatan, Indeks nilai penting \\ PRELIMINARY STUDY OF MANGROVE FOREST CONDITIONS IN KURAU TIMUR VILLAGE BANGKA TENGAH DISTRICT BANGKA BELITUNG ISLAND}

\begin{abstract}
Mangrove forest is one of the ecosystems found in Kurau Timur with various positive impacts that have made the mangrove one of the important values of the community there. Ordinarily the threat that occurs in the mangrove forest area in the Central Bangka Regency is that there are many unconventional tin mining activities that are often carried out by the community. Therefore, It required an assessment of the health condition of mangrove forests in the region in order to determine how the influence of the activity of human activities on the condition of mangrove in East Kurau. The purpose of this study was to measure the health level of mangrove forests that grow in the Kurau Timur area. The study was conducted from February to May 2019 in the Kurau Timur Village. The research data includes the density and important value index and hemispherical photography that has been agreed for the monitoring of mangrove in the COREMAP-CTI area. Based on the observations of Kurau Village, the east has mangrove cover between $77.22 \pm 2.64 \%$ to $88.89 \pm 1.71 \%$. Accordingly, this value is included in the good category when referring to the Decree of the Minister of Environment No. 201 of 2004. The type that dominates this station is Rhizophora apiculata with important value index values of $148,13 \%$ to $191.02 \%$. The majority of the substrate in the study site was sandy mud consequently it became a good habitat for mangroves, especially the types of Rhizophora apiculata group which dominated almost all research locations
\end{abstract}

\section{Keyword : Kurau Timur Village, diversity, important value index}




\section{Pendahuluan}

Mangrove merupakan salah satu ekosistem langka,karena luasnya hanya 2\% permukaan bumi. Indonesia merupakan kawasan ekosistem mangrove terluas di dunia. Mangrove mempunyai sejumlah bentuk khusus yang memungkinkan untuk hidup diperairan yang dangkal yaitu berakar pendek, menyebar luas dengan akar penyangga, atau ujung akarnya yang khusus tumbuh dari batang atau dahan. Hutan mangrove adalah kelompok jenis tumbuhan yang tumbuh disepanjang garis pantai tropis sampai sub-tropis yang memiliki fungsi istimewa disuatu lingkungan yang mengandung garam dan bentuk lahan berupa pantai dengan reaksi tanah an-aerob Vegetasi mangrove termasuk ekosistem pantai atau komunitas dangkal yang sangat menarik, yang terdapat pada perairan tropis atau subtropis (Farhaby, 2017). Vegetasi hutan mangrove di Indonesia memiliki keanekaragaman jenis yang tinggi, dengan jumlah jenis tercatat sebanyak 202 jenis yang terdiri dari 89 jenis pohon, 5 jenis palem, 14 jenis liana, 44 spesies epifit dan 1 jenis sikas. Namun demikian hanya terdapat kurang lebih 47 jenis tumbuhan spesifik hutan mangrove. Paling tidak di dalam hutan mangrove terdapat salah satu jenis tumbuhan sejati penting atau dominan yang termasuk ke dalam empat family yaitu : Rhizophoraceae (Rhizophora, Bruguiera, Ceriops), Sonneratiaceae (Sonneratia), Avicenniaceae (Avicenia) dan Meliaceae (Xylocarpus). (Bengen, 2004).

Salah satu kawasan hutan mangrove yang terdapat di Kabupaten Bangka tengah terletak di Desa Kurau Timur. Desa ini dapat ditempuh sekitar 35 menit melalui darat dari Kota Pangkalpinang dengan jarak sekitar $30 \mathrm{~km}$ dan 30 km dari Kota Kabupaten Bangka Tengah (Perda Kab Bangka Tengah, 2014). Kurau Timur merupakan satu dari beberapa desa di Kecamatan Koba yang memiliki beragam potensi wisata. Potensi wisata yang dimiliki Kurau Timur diantaranya sungai besar langsung menuju ke arah Laut Cina Selatan dengan pulau-pulau kecil yang indah seperti Pulau Ketawai, Pulau Gosong Asem, sungai dan Hutan Mangrove yang masih alami (Perda Kab Bangka Tengah, 2014). Mangrove merupakan komoditas yang terdapat di Kurau Timur dengan berbagai dampak positif yang dimilki menjadikan mangrove tersebut salah satu nilai penting bagi masyarakat disana, hal tersebut dikarenakan terdapat 319 orang yang berprofesi sebagai nelayan (Perda Kab BangkaTengah,2014). Kondisi ekosistem mangrove secara ekologis dinyatakan dapat mempengaruhi ekosistem lain yang berhubungan dengan ekosistem mangrove. Salah satu ekosistem yang terpengaruh oleh kondisi ekosistem mangrove adalah ekosistem karang dan lamun. Degradasi ekosistem mangrove akan menyebabkan peningkatan potensi kesehatan terumbu karang di dalam kawasan.

Secara umum, pemanfaatan hutan mangrove di Desa Kurau Timur secara lokal adalah pemanfaatan kayu yang berasal dari hutan mangrove untuk keperluan pembuatan atap rumah serta pembuatan arang. Ancaman lain adalah adanya aktivitas - aktivitas tambang timah inkonvensional yang marak dilakukan oleh masyarakat yang berada di daerah hulu dari sungai Kurau. Kajian awal mengenai bagaimana kondisi kesehatan hutan mangrove di Desa Kurau Timur perlu dilakukan untuk mengetahui bagaimana struktur komunitas di hutan mangrove Kurau Timur, tingkat kerapatannya serta Indeks Nilai Penting dari masing masing spesies yang ditemukan di kawasan tersebut, sebagai dasar untuk menentukan kondisi kesehatan hutan mangrove Desa Kurau Timur. Kajian awal ini memiliki tujuan utama dari penelitian ini adalah untuk mengukur dan mengetahui bagaimana kondisi kesehatan hutan mangrove yang tumbuh di kawasan Kurau Timur Kabupaten Bangka Tengah sebagai dasar untuk rekomendasi pengelolaan serta pemanfaatan yang berkelanjutan.

\section{Bahan dan Metode \\ Waktu dan Lokasi Penelitian}

Penelitian dilakukan pada bulan Februari sampai Mei 2019 di Desa Kurau Timur, Kabupaten Bangka Tengah Provinsi Kepulauan Bangka Belitung. Pengambilan data dilakukan sebanyak tiga stasiun (Gambar 1). Penentuan lokasi berdasarkan karakteristik habitat dan sebaran mangrove, sehingga dapat mewakli pengambilan data mengenai kesehatan komunitas mangove di Desa Kurau Timur. Identifikasi mangrove dilakukan di Laboratorium Manajemen Sumberdaya Perairan, Universitas Bangka Belitung. 


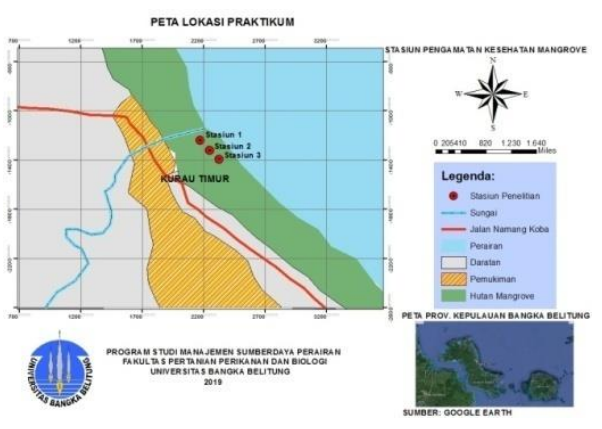

Gambar 1. Peta lokasi penelitian

\section{Pengambilan dan analisis data}

Data dikumpulkan dengan menggunakan metode plot garis dan fotografi hemisfer yang telah disepakati untuk pelaksanaan monitoring mangrove kawasan COREMAP-CTI (Darmawan dan Pramudji, 2014). Metode plot dibuat dan diletakkan pada setiap zona dibuat plot berukuran $10 \times 10 \mathrm{~m} 2 \mathrm{di}$ sepanjang garis untuk diukur diameter pohon pada ketinggian dada (DBH) yang memiliki lingkar batang minimal $16 \mathrm{~cm}$. Setelah dilakukan pengukuran terhadap diamter batang, maka batang yang sudah dihitung ditandai menggunakan cat semprot guna mempermudah penghitungan serta pemantauan lanjutan pada Tn. Plot awal pengamatan lalu dititik menggunakan gps dan kemudian dicatat titik koordinatnya sehingga dapat dipetakan secara baik dan memudahkan pemantauan pada tahun berikutnya.

Metode fotografi mengacu kepada penelitian Jenning et al. (1999) yang dimodifikasi. Dicatat jenis yang tumbuh didalam plot mengacu pada kepada Tomlinson (1986), Giesen et al. (2006) dan Noor et al. (2002) serta dihitung lingkar batang dan jumlah

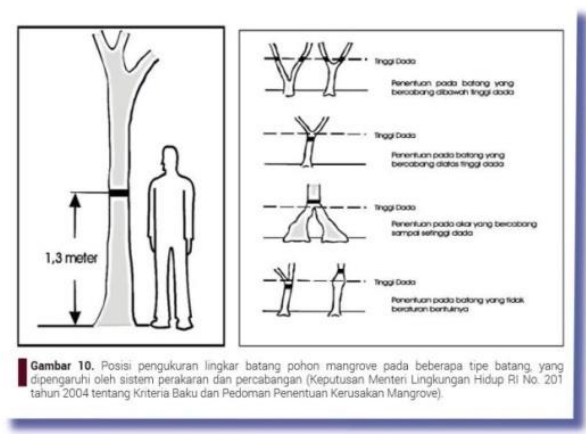

Gambar 2. Ilustrasi Pengukuran diameter pohon pada ketinggian dada (DBH) pohon di setiap plot. Metode fotografi dilakukan pada empat kuadran disetiap plot penelitian. Teknis pengambilan foto hemisphere adalah sebagai berikut pada setiap kuadran dilakukan pengambilan foto kearah langit dengan menggunakan kamera handhphone. Pengambilan foto ini bertujuan untuk mengetahui persen tutupan kanopi mangrove di kawasan yang sedang diamati. Hasil foto kemudian dianalisis dengan menggunakan software imageJ dengan menggunakan analisis perbandingan pixel yaitu antara pixel langit dengan pixel tanaman mangrove (Dharmawan dan Pramudji, 2014)

Parameter lain yang akan dianalisis adalah data kerapatan pohon dan persentase tutupan mangrove. Analisis data dilakukan dengan menggunakan analisis ANOVA dan dilanjutkan dengan uji beda nyata, Duncan dengan tujuan mengetahui dan mengidentifikasi perbedaan antar stasiun penelitian dalam lokasi pemantauan. Hasil analisis tersebut kemudian dibandingkan dengan menggunakan standar pengklasifikasian kesehatan mangrove berdasarkan Keputusan Menteri Lingkungan Hidup No. 201 tahun 2004.

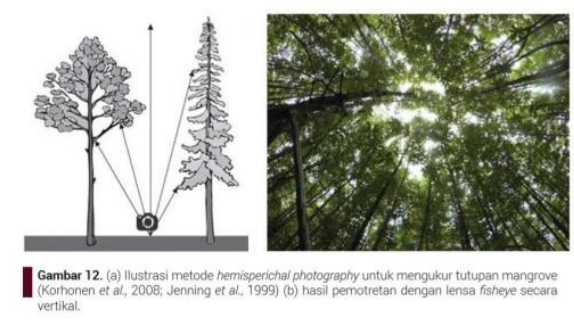

Gambar 3. Ilustrasi Pengukuran Hemispherical Photography

\section{Hasil dan Pembahasan \\ Komposisi dan Kerapatan Mangrove}

Berdasarkan hasil pengamatan Desa Kurau timur memiliki tutupan mangrove antara $77.22 \pm 2.64 \%$ sampai $88.89 \pm 1.71 \%$. Nilai tersebut termasuk kedalam kategori cukup baik dan baik apabila mengacu pada Keputusan Menteri Lingkungan Hidup No. 201 tahun 2004. Hasil pengamatan menunjukkan bahwa pada stasiun KTMM1 (Stasiun1) memiliki prosentase tutupan yang paling tinggi jika dibandingkan KTMM3 (stasiun3) dan KTMM2 (stasiun2). 
Tabel 1. Jumlah jenis, persentase tutupan mangrove, kerapatan dan INP jenis pada stasiun penelitian mangrove di Desa Kurau Timur

\begin{tabular}{|c|c|c|c|c|c|c|c|}
\hline \multirow{2}{*}{ No } & \multirow{2}{*}{ Lokasi } & \multirow{2}{*}{ Stasiun } & \multirow{2}{*}{$\begin{array}{c}\text { Jumlah } \\
\text { Jenis }\end{array}$} & \multirow{2}{*}{ \%cover } & \multirow{2}{*}{ Kerapatan } & \multicolumn{2}{|c|}{ INP } \\
\cline { 5 - 8 } & & & & Max & Min \\
\hline \multirow{2}{*}{$\mathbf{1}$} & \multirow{2}{*}{$\begin{array}{l}\text { Kurau } \\
\text { Timur }\end{array}$} & KTMM1 & 4 & $88.89 \pm 1.00^{\mathrm{bc}}$ & $1700 \pm 265$ & RA : $148,13 \%$ & BH : $16.12 \%$ \\
\cline { 5 - 8 } & & KTMM2 & 4 & $81.91 \pm 3.85^{\mathrm{c}}$ & $1600 \pm 153$ & RA : $191.02 \%$ & BG: $16.59 \%$ \\
\cline { 6 - 8 } & & 4 & $77.22 \pm 2.64^{\mathrm{bc}}$ & $2667 \pm 426$ & RA : $148.36 \%$ & BH : $25.57 \%$ \\
\hline
\end{tabular}

${ }^{a b}$ ANOVA, huruf yang berbeda pada kolom yang sama menunjukkan perbedaan secara nyata pada nilai \%tutupan dan kerapatan antar stasiun penelitian $(P<0.05)$

${ }^{x y}$ ANOVA, uji beda nyata digunakan untuk membedakan nilai \%tutupan dan kerapatan antar stasiun.

"Indeks nilai penting tertinggi dan terendah dalam setiap stasiun penelitian. Keterangan: RA: Rhizophora apiculata; BG: Bruguierra gymnorrhiza; BH : Bruguierra hainesii.

Berdasarkan hasil pengamatan di lokasi penelitian menunjukkan pada stasiun KTMM1 (Stasiun1) memiliki nilai persentase tutupan mangrove dan kerapatan pohon yang tinggi sebesar $1700 \pm 265$ pohon/ha. Jenis yang mendominasi pada stasiun ini adalah Rhizophora apiculata dengan nilai indeks nilai penting sebesar 148, $36 \%$. Berdasarkan analisis penutupan jenis mangrove, spesies mangrove yang di temukan di hutan mangrove desa Kurau Timur memiliki spesies yang berbeda antar masing- masing stasiun pengamatan. Pada kawasan ini banyak ditemukan mangrove jenis mayor yaitu tanaman mangrove yang membentuk kelompok dominan atau tegakan murni dan penyusun utama kawasan hutan mangrove (Tomlinson,1986). Jenis mangrove yang termasuk kedalam mangrove jenis mayor yaitu Rhizophora apiculata, Rhizophora mucronata, Avicennia sp dan Sonneratia alba. Zona ini terletak pada garis pantai yang berhadapan langsung dengan laut, memiliki salinitas paling tinggi dan umumnya subtrat berlumpur (Purnobasuki, 2005).

Hal ini kemungkinan disebabkan karena kawasan tersebut memiliki substrat pasir berlumpur yang sangat mendukung pertumbuhan mangrove jenis tersebut. Hal ini dikarenakan untuk spesies Rhizophora apiculata ditemukan mendominasi pada ekosistem dengan substrat pasir berlumpur dan cenderung mendekati ke arah muara (Farhaby, 2017). Jenis mangrove lain yang terdapat di stasiun ini adalah Rhizophora mucronata, Sonneratia alba, dan Bruguiera hainesii. Spesies dengan indeks nilai penting terendah adalah Bruguiera hainesii sebesar $16.12 \%$

Kawasan KTMM3 (Stasiun3) adalah stasiun yang memiliki nilai kerapatan tertinggi $2667 \pm 426$ pohon/ha. Hal ini dimungkinkan karena pada lokasi KTMM3 (stasiun3) letaknya di kawasan muara Sungai Kurau, KTMM3, merupakan wilayah yang memiliki keanekaragaman jenis yang tinggi. Pada kawasan ini ditemukan empat jenis mangrove yang didominasi oleh Rhizophora apiculata. Kawasan Sungai Kurau memiliki keragaman substrat yang cukup tinggi. Pada transek yang dekat dengan muara sungai, substrat didominasi oleh lumpuran sedangkan pada wilayah yang lebih jauh dari sungai memiliki substrat berpasir. Hal ini yang menyebabkan keanekaragaman jenis mangrove cukup tinggi. Persentase tutupan mangrove di kawasan ini mencapai $77.22 \pm 2.64 \%$. Nilai ini menunjukkan bahwa kondisi komunitas mangrove di muara Sungai kurau berdasarkan nilai tersebut maka kerapatan mangrove di lokasi penelitian termasuk dalam kriteria baik. Menurut SK Men. LH No.201 tahun 2004, untuk kriteria baku kerusakan mangrove berdasakan pedoman pemantauan kerusakan mangrove, kondisi ekosistem mangrove dapat digolongkan kedalam tiga kriteria yaitu jarang $<1000$ pohon/hektar (rusak), sedang $\geq 1000$ $<1500$ pohon/hektar (baik), dan sangat padat $\geq 1500$ pohon/hektar (baik).

Parameter lain mengenai kesehatan komunitas mangrove Selain nilai kerapatan, Indeks Keanekaragaman, serta Indeks Dominansi parameter yang paling penting untuk diketahui adalah Indeks Nilai Penting 
(INP). Indeks ini menyatakan kepentingan suatu jenis tumbuhan juga menggambarkan tingkat penguasaan jenis dalam komunitas. Indeks Nilai Penting juga memberikan suatu gambaran besarnya pengaruh dan peranan suatu jenis dalam suatu komunitas mangrove (Warongan,2009). Berdasarkan hasil analisis data maka dapat diketahui bahwa spesies yang memiliki nilai penting tertinggi untuk kategori pohon di Desa Kurau timur adalah Rhizophora apiculata. Menurut Warongan (2009), baik tidaknya pertumbuhan mangrove dalam suatu komunitas dapat dilihat dari analisis kondisi vegetasinya yang menunjukkan besar kecilnya peranan suatu jenis terhadap komunitas yang ada. Keadaan tersebut dapat dilihat dalam Indeks Nilai Penting yang dimiliki oleh suatu jenis mangrove. Nilai Penting yang tinggi menggambarkan bahwa jenis - jenis ini mampu bersaing dengan lingkungannya dan disebut jenis dominan. Sebaliknya, rendahnya Indeks Nilai Penting pada jenis tertentu mengindikasikan bahwa jenis tersebut kurang mampu bersaing dengan lingkungan yang ada di sekitarnya serta kurang mampu bersaing dengan jenis lainnya. Rendahnya ketahanan terhadap gejala alam serta besarnya eksploitasi mengakibatkan jenis-jenis tersebut berkurang jumlahnya dari tahun ke tahun.

\section{Parameter Lingkungan}

Kisaran salinitas yang teramati pada saat penelitian sebesar $15-35$ ppt. Salinitas merupakan gambaran jumlah garam dalam suatu perairan (Dahuri et al.,2004). Kusmana et al. (2003) menyatakan bahwa tanaman mangrove dapat tumbuh dengan baik pada kisaran salinitas 10-30 ppt. Meskipun demikian dengan kisaran salinitas yang teramati, mangrove di lokasi masih dapat tumbuh hal ini dikarenakan pada saat pengamatan kondisi perairan sedang surut. Nontji (2005) menyatakan bahwa sebaran salinitas di air laut dipengaruhi oleh berbagai faktor seperti pola sirkulasi air, penguapan, dan curah hujan. Selain salinitas, suhu air juga merupakan faktor penting yang menentukan kehidupan tumbuhan mangrove. Suhu perairan yang teramati pada saat penelitian berkisar $24-30^{\circ} \mathrm{C}$, hal ini sesuai dengan pernyataan Kennis (1990) dan Supriharyono (2007)yang menyatakan bahwa mangrove dapat tumbuh dengan subur di daerah tropis pada kisaran suhu lebih dari $20^{\circ} \mathrm{C}$.
Tipe pasang surut di lokasi penelitian merupakan tipe pasang surut campuran dimana penggenangan 1-2 kali dalam sehari atau minimal 20 hari dalam sebulan dengan julat pasang mencapai $1 \mathrm{~m}$. Curah hujan di Desa Kurau Timur sebesar 1.943 mm/th, hal ini sesuai dengan pernyataan Aksornkoae (1993)bahwa umumnya tumbuhan mangrove tumbuh dengan baik pada daerah dengan ratarata curah hujan $1500-3000 \mathrm{~mm} / \mathrm{th}$.

Pemantauan kondisi kesehatan mangrove di Desa Kurau Timur secara berkelanjutan baru dilaksanakanpada tahun 2019, Stasiun yang digunakan dalam penelitian ini merupakan stasiun permanen yang akan dimonitoring secara berkelanjutan setiap tahunnya guna mengetahui apakah ada perubahan terkait dengan spesies yang ditemukan, tingkat kerapatan, tutupan kanopi dan Indeks Nilai Penting dari masing masing spesies yang diketemukan dalam lokasi penelitian. Data - data tersebut nantinya dapat berfungsi sebagai parameter kondisi kesehatan ekosistem mangrove di Desa kurau Timur yang akan digunakan sebagai bahan pertimbangan dalam manajemen tata kelola pesisir di Kabupaten Bangka tengah.

\section{Kesimpulan}

Desa Kurau Timur Kabupaten Bangka Tengah, memiliki komunitas mangrove dengan kondisi tutupan dan nilai kerapatan yang masih tergolong baik. Kondisi ini diduga disebabkan oleh sangat bervariasinya kondisi substrat yang ditemukan. Mayoritas substrat pada lokasi penelitian adalah lumpur berpasir sehingga menjadi habitat yang baik bagi tanaman mangrove terutama jenis Kelompok Rhizophora apiculata yang mendominasi hampir disemua lokasi penelitian dengan indeks nilai penting antara 148, 13\% hingga $191.02 \%$.

Hasil pengamatan di Desa Kurau timur juga menunjukkan bahwa terdapat total empat spesies lain yang ditemukan di kawasan Hutan mangrove desa Kurau Timur Rhizophora mucronata, Sonneratia alba, Avicennia marina dan Bruguiera hainesii.

Parameter lingkungan yang diukur pada lokasi pengamatan menunjukkan bahwa kawasan Desa Kurau Timur memang memiliki parameter yang mendukung bagi pertumbuhan optimum tanaman mangrove 
seperti salinitas, suhu perairan, curah hujan, dan tipe substrat sedimen yang menunjang pertumbuhan optimum bagi komunitas mangrove.

\section{Ucapan Terimakasih}

Penulis ucapkan terimakasih kepada COREMAP-CTI untuk kegiatan Pelatihan Penilaian Kondisi Komunitas Mangrove serta metode yang digunakan dalam penulisan artikel ini. Terima kasih juga penulis sampaikan kepada Center Aquatic Resources And Small Islands Studies (Carsis) Universitas Bangka Belitung yang telah memfasilitasi tempat dan meminjamkan peralatan untuk pengambilan data, sehinggapenelitianini dapat terlaksana hingga selesai.

\section{Daftar Pustaka}

Aksornkoae, S. 1993. Ecology and Management of Mangrove. IUCN. Bangkok.Thailand. 176 hal

Bengen, D.G., 2004. Mengenal dan Memelihara Mangrove. Pusat Kajian Sumber Daya Pesisir dan Lautan IPB, Bogor.

Dahuri, R., J. Rais., S. P. Ginting., M. J. Sitepu. 2004.

Pengelolaan

SumberdayaWilayah Pesisir dan Laut Secara Terpadu. Edisi revisi. PT. Pradnya Paramita. Jakarta.

Dharmawan, I.W.E. \& Pramudji. 2014. Panduan Monitoring Status Kesehatan Komunitas Mangrove. CRITC COREMAP CTI LIPI. PT. Sarana Komunikasi Utama. Bogor.

Farhaby, A.M., 2017. Kajian Karakteristik Biometrika Kepiting Bakau (Scylla sp) di Kabupaten Pemalang, Studi kasus di Desa Mojo Kecamatan Ulujami. Akuatik:Jurnal Sumberdaya
Perairan, 11(1).

Giesen, W., S. Wulffraat, M. Zieren \& L. Scholten. 2006. Mangrove Guidebook for Southeast Asia. FAO and Wetlands International. Bangkok.

Jenning, S.B., N.D. Brown \& D. Sheil. 1999. Assessing forest canopies and understorey illumination: canopy closure, canopy cover and other measures. Forestry 72(1): 59-74.

Keputusan Menteri Lingkungan Hidup No. 201 Tahun 2004 tentang Kriteria baku dan Pedoman Penentuan Kerusakan Mangrove.

Kusmana, C., S. Wilarso, I. Hilwan, P. Pamoengkas, C. Wibowo, T. Tiryana,A. Triswanto,Yunasfi, Hamzah.2003. Teknik Rehabilitasi Mangrove. Fakultas Kehutanan. Institut Pertanian Bogor. Bogor.

Nontji, A. 2005. Laut Nusantara (Edisi revisi). Djambatan, Jakarta.

Peraturan Daerah Kabupaten Bangka Tengah Nomor 21 Tahun 2014 Tentang Rencana Zonasi Wilayah Pesisir Dan Pulau-Pulau Kecil Kabupaten Bangka Tengah Tahun 2014-2034

Purnobasuki, H. 2005. Tinjauan Perspektif Hutan Mangrove. Airlangga. University Press. 95 hal.

Supriharyono. 2007. Konservasi Ekosistem Sumberdaya Hayati di Wilayah Pesisir dan Laut Tropis. Pustaka Pelajar, Yogyakarta.

Warongan, C.W.A. 2009. Kajian Ekologi Ekosistem Mangrove untuk Rehabilitasi di Desa Tiwoho Kecamatan Wori Kabupaten Minahasa Utara Prov. Sulawesi Utara. Tesis PascaSarjana Institut Pertanian Bogor. Bogor. 